DOI: https://doi.org/10.47405/mjssh.v6i12.1209

\begin{tabular}{|c|c|}
\hline 4.581 & Malaysian Journal of Social Sciences and Humanities (MJSSH) \\
\hline $\begin{array}{l}\text { Malaysian Journa of } \\
\text { socal selenes and }\end{array}$ & Volume 6, Issue 12, December 2021 \\
\hline (MJ-SSH) & e-ISSN : 2504-8562 \\
\hline & $\begin{array}{l}\text { Journal home page: } \\
\text { www.msocialsciences.com }\end{array}$ \\
\hline
\end{tabular}

\title{
Tahap Kemurungan dalam kalangan Jururawat di Fasiliti Kesihatan Kuala Lumpur
}

\author{
Siti Nurhanim Mohamed Aimanan', Farah Aleah Zainul Rijal², Albeny Joslyn Panting1, \\ Nadia Amirudin ${ }^{\text {, }}$ Rosnani Kassim ${ }^{1}$, Manimaran Krishnan Kaundan ${ }^{1}$, Norbaidurah Ithnain ${ }^{1}$ \\ ${ }^{1}$ Institut Penyelidikan Tingkahlaku Kesihatan, Institut Kesihatan Negara (NIH), Kementerian \\ Kesihatan Malaysia (KKM), Malaysia \\ 2Universiti Islam Antarabangsa Malaysia (UIAM), Malaysia
}

Correspondence: Siti Nurhanim Mohamed Aimanan (anim_iman@yahoo.com)

\begin{abstract}
Abstrak
Kajian ini bertujuan untuk mengetahui tahap kemurungan dan juga perbezaan antara tahap kemurungan mengikut ciri-ciri demografi jururawat di Kuala Lumpur. Kajian rentas ini telah dijalankan ke atas 145 orang jururawat bermula daripada bulan Julai 2015 sehingga Januari 2016. Soalan Beck Depression Inventory 11 (BDI 11) telah digunakan bertujuan untuk mengukur simptom dan tahap kemurungan yang dialami oleh responden. Data kemudiannya dianalisis dengan menggunakan perisian SPSS versi 21. Bagi menguji tahap perbezaan antara komponen kemurungan dengan maklumat demografi, Ujian $T$ Tidak Bersandar dan Ujian Anova Sehala telah dijalankan. Dapatan menunjukkan 88 orang jururawat berada pada tahap kemurungan minimum, 26 orang pada tahap biasa, 27 orang pula pada tahap sederhana dan 4 orang mengalami kemurungan yang teruk. Bagi menguji perbezaan tahap kemurungan untuk maklumat demografi, didapati hanya faktor umur sahaja yang mempunyai perbezaan signifikan $(\mathrm{p}<.05)$ namun bagi maklumat demografi lain seperti jantina, tahap perkahwinan, pendapatan, tempoh bertugas semasa dan juga tempoh perkhidmatan menunjukkan tiada perbezaan signifikan $(p>.05)$. Dapatan kajian ini boleh membantu dalam menyediakan modul dan program intervensi bagi memastikan jururawat yang sentiasa terdedah dan berisiko terhadap masalah mental ini mempunyai pengetahuan dan kemahiran yang tinggi dalam mengawal tekanan emosi semasa menjalankan tugas.
\end{abstract}

Kata kunci: kemurungan, jururawat, emosi

\section{Levels of Depression Among Nurses in Health Facilities Kuala Lumpur}

\begin{abstract}
This study aims to determine the level of depression and also the difference between the level of depression according to the demographic characteristics of nurses in Kuala Lumpur. This crosssectional study was conducted on 145 nurses starting from July 2015 to January 2016. Beck Depression Inventory 11 (BDI 11) was used to measure the symptoms and level of depression experienced by the respondents. The data was collected and analyzed using SPSS version 21 . To test the level of difference between the depression component with demographic information, the Independent T-Test, and One-Way Anova test was conducted. The findings showed that 88 nurses were at a minimum level of depression, 26 people at a normal level, 27 people at a moderate level, and 4 people had severe depression. In terms of differences between the level of depression and demographic information, this study found that only age factors had significant differences $(p<.05)$ but for other demographic information such as gender, marital level, income, period of current service,
\end{abstract}


and also period of service showed no significant ( $\mathrm{p}>.05$ ). The findings of this study can help in providing modules and intervention programs to ensure that nurses who are constantly exposed and at risk for these mental problems have high knowledge and skills in controlling emotional stress while performing tasks.

Keywords: depression, nursing, emotions

\section{Pengenalan}

Dewasa ini status negara membangun dan urbanisasi telah mewujudkan gaya hidup tidak sihat dan menimbulkan tekanan yang berlebihan sehingga menyebabkan pelbagai masalah kesihatan yang rumit termasuk kesihatan mental (Yeap \& Low, 2009). Masalah kesihatan mental ini boleh terjadi kepada sesiapa sahaja tanpa mengenal umur, bangsa dan status kesihatan (Yahya \& Md. Sham, 2020). Masalah ini tidak hanya berlaku dengan sendirinya namun ianya boleh terjadi disebabkan oleh faktor-faktor yang berada di sekeliling individu itu sendiri (Mohd Suhaimi \& Mohd Haazik, 2020). Oleh yang demikian, kemurungan adalah salah satu jenis penyakit mental yang biasa terjadi selain daripada tekanan, kebimbangan, kecelaruan pemakanan dan skizofrenia. Masalah ini boleh berlaku melibatkan perubahan pemikiran, emosi, perasaan dan tingkah laku yang menyebabkan kehidupan seharian menjadi sukar dan jika tidak dirawat ia akan memberi kesan yang buruk kepada individu dan masyarakat (Yahya \& Md. Sham, 2020).

Berdasarkan laporan Pertubuhan Kesihatan Sedunia pada tahun 2015 mendapati pada peringkat global jumlah keseluruhan individu yang menghidapi gangguan mental kemurungan adalah seramai 322 juta orang. Golongan wanita mencatatkan kadar kelaziman gangguan mental kemurungan paling tinggi iaitu 5.1 peratus berbanding lelaki sebanyak 3.6 peratus (World Health Organization, 2017). Manakala di Malaysia pula, melalui Tinjauan Kebangsaan Kesihatan Malaysia yang dijalankan pada tahun 2011 oleh Kementerian Kesihatan menunjukkan bahawa penyakit kesihatan mental akan menjadi masalah kesihatan yang utama dialami oleh rakyat menjelang tahun 2020 (Kementerian Kesihatan Malaysia, 2011). Masalah ini bukan bersifat sementara dan bukan sesuatu yang boleh ditamatkan dan dihilangkan dengan keinginan semata-mata tetapi perlu dirawat dengan bantuan pakar dan ubat (Hanidah, 2013).

Pelbagai kesan atau impak negatif boleh berlaku terutamanya daripada sudut kesihatan pekerjaan seperti darah tinggi, kemurungan, tekanan perasaan, masalah jantung, serta kematian jika tiada langkah proaktif atau pencegahan diambil di peringkat awal bagi mengatasi masalah tekanan atau stres yang berlaku. Apabila pekerja berasa tertekan dan ianya terus berulang semasa melakukan tugas, maka kecenderungan mereka mendapat kecederaan atau kemalangan adalah tinggi (Ganing et al., 2020). Bidang perguruan, kejururawatan dan khidmat pelanggan, dipercayai kerjaya paling berisiko tinggi menyumbang kepada tekanan dan kemurungan dalam kalangan pekerja wanita, berikutan pelbagai isu antaranya seperti terpaksa berulang-alik pada jarak jauh ke tempat kerja (Halina, 2019). Sebagai profesion yang tergolong dalam bidang perkhidmatan dan pengurusan, bidang kejururawatan merupakan antara pekerjaan yang penuh dengan cabaran dan memerlukan ketahanan mental dan fizikal yang tinggi (Aisha \& Ruslan, 2020).

Semenjak beberapa tahun kebelakangan ini, profesion kejururawatan dilaporkan menjadi salah satu bidang paling tertekan sama ada di negara maju mahupun di negara yang sedang membangun (Tran et al., 2019). Sebagai petugas kesihatan yang sentiasa berdepan dengan pelbagai cabaran dalam menyampaikan perkhidmatan kesihatan kepada masyarakat, jururawat sentiasa terdedah dengan masalah kemurungan ini. Profesion ini menuntut tanggungjawab dan pengetahuan yang sangat tinggi seterusnya boleh menyebabkan jururawat mengalami kemurungan atau perasaan marah yang boleh mengakibatkan penderitaan kepada pesakit dan ahli keluarga mereka sendiri. Tekanan yang berterusan juga boleh menyebabkan kepada burnout dalam kalangan jururawat (Ayub, 2008). Hal ini juga memberi kesan kepada kehidupan, perhubungan, prestasi kerjaya dan kurang keyakinan diri (Abdullah et al., 2018). Secara keseluruhannya, bidang kejururawatan adalah kerja perkhidmatan yang memerlukan pelbagai interaksi interpersonal yang berkesan. Beban kerja yang tinggi di samping merawat pesakit dengan 
keadaan yang lebih teruk memerlukan jururawat untuk mempunyai lebih banyak hubungan dengan doktor, jururawat dan saudara-mara pesakit yang lain. Hal ini boleh menyebabkan kebingungan di samping meningkatkan tekanan jiwa mereka (Lee \& Kim, 2015).

Oleh yang demikian, masalah kemurungan dalam kalangan pekerjaan sememangnya sering terjadi dan perlu ditangani dengan berhati-hati. Tidak kira sama ada dalam kalangan mereka yang bekerja di sektor perkhidmatan kesihatan atau sebaliknya, masalah ini perlu dipandang serius agar tidak memberi impak yang negatif dalam kehidupan seharian. Menurut Mohamed (2001), kemurungan yang tidak dirawat akan memberi kesan kepada keupayaan seseorang untuk melaksanakan tanggungjawab serta tugas harian kerana ia berkait dengan masalah emosi dan ragam manusia. Oleh itu, impak kemurungan memberi kesan yang negatif kepada individu yang memerlukan pemerhatian yang lebih serius bagi membendung daripada terus berpanjangan sehingga boleh mengakibatkan kepada penyakit mental yang serius.

\section{Penyataan Masalah}

Kajian dalam bidang psikologi termasuk dari aspek kemurungan yang dihadapi dalam kalangan jururawat banyak dijalankan sama ada di peringkat Malaysia mahupun di seluruh dunia. Namun demikian, kajian khusus bagi jururawat yang bertugas di kawasan mempunyai kepadatan penduduk yang tinggi adalah kurang dijalankan di Malaysia. Jururawat dengan kemahiran yang telah dilatih untuk menangani masalah fizikal dan mental sewaktu dalam tempoh latihan sebelum bertugas di lapangan perlu dikaji, sama ada dapat mengawal tekanan semasa bertugas. Hal ini penting bagi memastikan perkhidmatan kesihatan yang diberikan oleh jururawat tidak dipengaruhi oleh sebarang faktor negatif yang boleh menimbulkan masalah kepada jururawat sama ada dari segi aspek fizikal dan mental. Namun demikian, profesion kejururawatan lebih terdedah kepada masalah psikologi yang berbeza kerana tekanan kerja. Salah satu penyumbang terhadap masalah ini adalah tempoh jangka masa yang lama berjumpa dengan pesakit adalah menjadi satu cabaran utama (Sehrish \& Waqar, 2020). Oleh yang demikian, kajian ini bertujuan untuk mengenal pasti tahap kemurungan dan juga perbezaan tahap kemurungan dalam kalangan jururawat yang bertugas di fasiliti kesihatan di Kuala Lumpur.

\section{Objektif kajian}

Objektif kajian akan menjelaskan arah tuju sebenar kajian yang dijalankan dan berikut adalah objektif kajian:

i. Mengenal pasti tahap kemurungan dalam kalangan jururawat.

ii. Mengenal pasti perbezaan tahap kemurungan mengikut maklumat demografi dalam kalangan jururawat.

\section{Sorotan Literatur}

\section{Kemurungan}

Kemurungan menurut perspektif psikologi adalah rasa kecewa, putus asa, hiba dan sedih yang berpanjangan sehingga tidak tertanggung oleh individu itu sendiri (Fariza, 2019). Pertubuhan Kesihatan Sedunia (WHO) mendefinisikan kemurungan sebagai gangguan mental yang biasa hadir dengan perasaan tertekan, kehilangan minat atau keseronokan, penurunan tenaga, perasaan bersalah atau rendah harga diri, gangguan tidur atau selera makan dan miskin kepekatan (Marcus et al., 2012). Dalam konteks kesihatan psikologi di Malaysia pula Kementerian Kesihatan Malaysia mendefinisikan kemurungan adalah gangguan perasaan yang menyebabkan seseorang itu merasa sedih yang berpanjangan, keletihan dan ketiadaan tenaga, cepat marah serta kehilangan minat dalam aktiviti harian yang boleh berlarutan sekurang-kurangnya dalam masa dua minggu. Penyakit ini boleh dihidapi kepada 
sesiapa sahaja tidak kira umur, jantina atau bangsa. Kemurungan boleh berlangsung dalam tempoh masa yang lama sehingga berbulan-bulan atau bertahun-tahun (Ahmad, 2018).

Episod kemurungan adalah melibatkan gejala seperti tekanan emosi, kehilangan minat, keseronokan dan peningkatan keletihan dalam menjalankan aktiviti harian. Episod kemurungan ini boleh dikategorikan sebagai ringan, sederhana dan teruk bergantung kepada bilangan dan keparahan gejala yang dihadapi oleh seseorang. Individu yang menghadapi episod kemurungan yang ringan akan mengalami kesukaran untuk meneruskan pekerjaan dan aktiviti sosial seperti biasa namun mungkin tidak akan berhenti berfungsi secara sepenuhnya. Namun sebaliknya bagi individu yang mengalami episod kemurungan yang teruk boleh mengakibatkan individu tersebut tidak dapat meneruskan sebarang aktiviti sosial, pekerjaan atau urusan rumah tangga kecuali dalam tahap yang sangat terhad (Marcus et al., 2012).

Faktor- faktor penyebab terhadap kemurungan adalah terdiri daripada aspek biologi, genetik, personaliti dan persekitaran. Namun demikian simptom kemurungan adalah berbeza mengikut individu kerana ianya boleh berubah mengikut tahap umur, kematangan dan persekitarannya yang pada asasnya boleh dilihat dari segi afektif, kognitif, tingkah laku dan fisiologi (Nasir et al., 2016). Di samping itu juga, seseorang yang mengalami kemurungan akan mengalami beberapa masalah lain seperti insomnia, keletihan emosi dan fizikal dan kebimbangan (Bahari \& Nawi, 2016). Semua aspek ini adalah saling berkaitan antara satu sama lain. Beck dan Alford (1967) juga menyatakan corak pemikiran yang tidak berfungsi boleh menyebabkan kemurungan apabila seseorang itu tidak percaya kepada dirinya. Kesemua simptom ini memerlukan pengawasan dan penjagaan yang rapi. Kemurungan secara keseluruhannya merupakan penyakit yang wujud dan mempunyai punca dan simptom yang nyata (Yahya \& Md. Sham, 2020).

\section{Metod Kajian}

\section{Reka Bentuk Kajian dan Pensampelan}

Pendekatan kajian secara kuantitatif digunakan bertujuan untuk mengkaji tahap kemurungan dalam kalangan jururawat Kementerian Kesihatan Malaysia yang bertugas di Kuala Lumpur. Kaedah soal selidik secara kajian rentas (cross-sectional) digunakan untuk mengumpul data dalam kajian ini. Responden terdiri daripada jururawat yang bertugas di klinik kesihatan, klinik kesihatan ibu dan anak dan juga klinik 1 Malaysia di Kuala Lumpur. Pengiraan saiz pensampelan adalah menggunakan kaedah pengiraan oleh Krejcie Morgan melibatkan seramai 145 orang jururawat daripada sejumlah 207 orang jururawat sebagai responden (Krejcie, 1970). Kaedah pensampelan yang digunakan dalam kajian ini adalah kaedah pensampelan rawak berstrata. Kajian ini telah memperoleh kelulusan etika daripada Jawatankuasa Etika dan Penyelidikan Perubatan (MREC).

\section{Instrumen Kajian}

Soal selidik ujian Beck Depression Inventory 11 (BDI 11) digunakan untuk mengukur aspek kemurungan responden yang mengandungi 21 item (Beck et al., 1961). Nilai ketekalan dalaman BDI 11 versi Melayu ini adalah tinggi iaitu sebanyak 0.86 (Norhayati et al., 2010). Alat kajian ini sesuai digunakan ke atas remaja berusia 14 tahun dan ke atas serta orang dewasa. Tatacara pemarkahan dan prosedur pemarkahan alat ujian BDI 11 ini adalah dengan menggunakan 21 item yang kebanyakan simptom dinilai berdasarkan 4 sub skala jawapan dengan skala 0 hingga 3 . Seterusnya markah yang diperoleh oleh responden akan dinilai menggunakan skala tafsiran seperti berikut:

$\begin{array}{cl}\text { i.0-13 } & \text { : Kemurungan minimum } \\ \text { ii.14-19 } & : \text { Kemurungan biasa } \\ \text { iii.20-28 } & : \text { Kemurungan sederhana } \\ \text { iv.29-63 } & : \text { Kemurungan teruk }\end{array}$


Kajian rintis telah dijalankan adalah melibatkan seramai 20 orang responden dalam kalangan jururawat yang juga bertugas di salah sebuah klinik kesihatan di Kuala Lumpur. Fasiliti kesihatan ini dipilih berdasarkan ciri-ciri responden yang mempunyai persamaan dengan kajian sebenar.

\section{Hasil Kajian}

\section{Profil Responden Kajian}

Sebanyak 145 soal selidik telah diedarkan kepada responden dan telah dijawab dengan lengkap. Berdasarkan Jadual 1, 97.2\% responden adalah perempuan dan 2.8\% adalah lelaki. Manakala untuk taraf perkahwinan $80.7 \%$ telah berkahwin, $17.2 \%$ bujang dan $2.1 \%$ responden adalah duda atau janda. Majoriti responden adalah daripada kategori umur antara 25 hingga 34 tahun (55.9\%) diikuti dengan 35 hingga 44 tahun (27.6\%), 18 hingga 24 tahun (9.0\%), 45 hingga 54 tahun (6.9\%) dan 55 sehingga 60 tahun $(0.7 \%)$.

Bagi pendapatan kasar sebulan pula, kebanyakan responden mempunyai pendapatan kasar sebulan antara RM2000 hingga RM2999 (45.5\%) diikuti RM3000 hingga RM 3999 (29.7\%), RM1000 hingga RM1999 (17.2\%), RM4000 hingga RM4999 (5.5\%) dan lebih daripada RM5000 (2.1\%). Responden yang memiliki bilangan anak antara 1 hingga 2 orang adalah sebanyak $44.1 \%$, belum memiliki anak sebanyak 26.2\%, 3 hingga 4 orang sebanyak $25.5 \%$ dan 5 orang dan lebih sebanyak $4.1 \%$. Majoriti responden telah bertugas di fasiliti kesihatan melebihi 12 bulan di klinik tempat berkhidmat sekarang (75.9\%) berbanding responden yang sudah bertugas selama 6 bulan hingga 12 bulan di klinik sekarang (24.1\%). Selain itu, responden yang mempunyai tempoh perkhidmatan dengan Kementerian Kesihatan Malaysia menunjukkan bahawa sebanyak 62.8\% telah berkhidmat selama 2 hingga 10 tahun, 30.2\% selama 11 hingga 20 tahun, dan $6.9 \%$ selama lebih daripada 21 tahun.

Jadual 1: Profil demografi jururawat $(\mathrm{N}=145)$

\begin{tabular}{lll}
\hline \multicolumn{1}{c}{ Pemboleh ubah } & Bilangan (n) & Peratus (\%) \\
\hline Jantina & 141 & 97.2 \\
Perempuan & 4 & 2.8 \\
Lelaki & & \\
Taraf perkahwinan & 117 & 80.7 \\
Berkahwin & 25 & 17.2 \\
Bujang & 3 & 2.1 \\
Duda/Janda & & \\
Umur & 81 & 55.9 \\
25-34 tahun & 40 & 27.9 \\
35-44 tahun & 13 & 9.0 \\
18- 24 tahun & 10 & 6.9 \\
45-54 tahun & 1 & 0.7 \\
55-60 tahun & & \\
Pendapatan kasar sebulan & 66 & 45.5 \\
RM 2000 - RM 2999 & 43 & 29.7 \\
RM 3000 - RM 3999 & 25 & 17.2 \\
RM 1000 - RM 1999 & 8 & 5.5 \\
RM 4000 - RM 4999 & 3 & 2.1 \\
> RM 5000 & & \\
Bilangan anak & 38 & 26.2 \\
Belum memiliki anak & 64 & 44.1 \\
1 - 2 orang & 37 & 25.5 \\
3 - 4 orang & 6 & 4.1 \\
5 orang dan lebih & & \\
Tempoh perkhidmatan di klinik sekarang & 110 & 75.9 \\
Lebih daripada 12 bulan & &
\end{tabular}


6 bulan -12 bulan

Tempoh perkhidmatan dengan Kementerian Kesihatan

Malaysia

$2-10$ tahun

$11-20$ tahun

21 tahun dan lebih
35

$91 \quad 62.8$

$44 \quad 30.3$

$10 \quad 6.9$

\section{Tahap Kemurungan}

Jadual 2 melaporkan peratusan tahap kemurungan responden yang terlibat dalam kajian ini. Sebanyak $60.7 \%$ (88) responden mengalami kemurungan minimum, 17.9\% (26) mengalami kemurungan biasa, $18.6 \%$ (27) mengalami kemurungan sederhana dan $2.8 \%$ (4) responden pula mengalami kemurungan yang teruk.

Jadual 2: Peratusan tahap kemurungan responden $(\mathrm{N}=145)$

\begin{tabular}{lll}
\hline Kategori & Bilangan $(\mathbf{n})$ & Peratus(\%) \\
\hline Kemurungan Minimum & 88 & 60.7 \\
Kemurungan Biasa & 26 & 17.9 \\
Kemurungan Sederhana & 27 & 18.6 \\
Kemurungan Teruk & 4 & 2.8 \\
\hline
\end{tabular}

\section{Perbezaan Kemurungan Berdasarkan Demografi}

Analisis - Ujian T-Tidak Bersandar dan Anova Sehala telah digunakan untuk mengenal pasti perbezaan tahap kemurungan mengikut maklumat demografi iaitu terdiri daripada jantina, tempoh perkhidmatan di klinik sekarang, taraf perkahwinan, umur, pendapatan kasar sebulan, bilangan anak dan tempoh perkhidmatan dengan Kementerian Kesihatan Malaysia.

Jadual 3: - Ujian T-Tidak Bersandar untuk Jantina dan Tempoh Perkhidmatan di Klinik Sekarang

\begin{tabular}{|c|c|c|c|c|c|}
\hline $\begin{array}{l}\text { Pemboleh } \\
\text { ubah }\end{array}$ & Min (S.P) & & $\begin{array}{l}\text { Perbezaan Min (95\% } \\
\text { CI) }\end{array}$ & $\begin{array}{l}\text { Nilai-t } \\
\text { (df) }\end{array}$ & $\begin{array}{l}\text { Nilai } \\
\mathbf{p}\end{array}$ \\
\hline \multirow[t]{5}{*}{ Kemurungan } & Jantina & & & & \\
\hline & Lelaki & Perempuan & \multirow{2}{*}{$\begin{array}{l}5.76596(-3.12039 \\
14.65231)\end{array}$} & \multirow{2}{*}{1.283} & \multirow{2}{*}{0.202} \\
\hline & $17.000(8.04156)$ & $11.2340(8.88308)$ & & & \\
\hline & \multicolumn{2}{|c|}{$\begin{array}{l}\text { Tempoh Perkhidmatan di } \\
\text { Klinik Sekarang }\end{array}$} & & & \\
\hline & $\begin{array}{l}\text { Lebih daripada } 12 \\
\text { bulan } \\
11.1000(9.16009)\end{array}$ & $\begin{array}{l}6-12 \text { bulan } \\
12.3143(8.01752)\end{array}$ & $\begin{array}{l}-1.21429(-4.62910 \\
2.20053)\end{array}$ & -0.703 & 0.483 \\
\hline
\end{tabular}

$\mathrm{N}=145, *$ Significant level at 0.05

Kajian mendapati bahawa hanya terdapat perbezaan signifikan antara tahap kemurungan dengan umur (sig=0.030, $\mathrm{p}<0.05$ ). Hal ini membuktikan bahawa tahap kemurungan dalam peringkat umur adalah berbeza. Sementara itu, perbezaan tahap kemurungan responden adalah tidak signifikan untuk jantina ( $\operatorname{sig}=0.679, \mathrm{p}>0.05)$, tempoh perkhidmatan di klinik sekarang $(\mathrm{sig}=0.211, \mathrm{p}>0.05)$, taraf perkahwinan $(\mathrm{sig}=0.994, \mathrm{p}>0.05)$, pendapatan kasar sebulan $(\operatorname{sig}=0.861, \mathrm{p}>0.05)$, bilangan anak $(\operatorname{sig}=0.254, \mathrm{p}>0.05)$ dan tempoh perkhidmatan dengan Kementerian Kesihatan Malaysia (sig=0.405, p>0.05). 
Jadual 4: Ujian Anova Sehala Analisis untuk maklumat demografi

\begin{tabular}{|c|c|c|c|c|}
\hline Pembolehubah & & $\operatorname{Min}(\mathbf{S . P})$ & $\begin{array}{l}\text { Nilai-F } \\
\text { (df) }\end{array}$ & Nilai $p$ \\
\hline \multirow[t]{3}{*}{ Taraf Perkahwinan } & Berkahwin & $11.3559(8.99907)$ & & \\
\hline & Bujang & $11.5417(8.83166)$ & $0.006(144)$ & 0.994 \\
\hline & Duda/Janda & $11.6667(8.88608)$ & & \\
\hline \multirow[t]{5}{*}{ Umur } & 18-24 tahun & $7.5455(9.07043)$ & $2.760(144)$ & 0.03 \\
\hline & 25-34 tahun & $13.4337(9.04891)$ & & \\
\hline & 35-44 tahun & $8.7250(7.64262)$ & & \\
\hline & 45-54 tahun & $9.5000(8.97218)$ & & \\
\hline & 55-60 tahun & 10.0000 & & \\
\hline \multirow[t]{5}{*}{ Pendapatan kasar sebulan } & RM1000 - RM1999 & $10.6087(8.91750)$ & $.325(144)$ & 0.861 \\
\hline & RM2000 - RM2999 & $12.1385(9.85659)$ & & \\
\hline & RM3000 - RM3999 & $11.2174(7.65336)$ & & \\
\hline & RM4000 - RM4999 & $9.8750(7.91811)$ & & \\
\hline & > RM5000 & $8.0000(10.58301)$ & & \\
\hline \multirow[t]{4}{*}{ Bilangan anak } & Belum memiliki anak & $11.7778(8.88608)$ & $1.373(144)$ & 0.254 \\
\hline & $1-2$ orang & $12.6875(8.94760)$ & & \\
\hline & $3-4$ orang & $9.1538(9.08596)$ & & \\
\hline & 5 orang dan lebih & 9.8333(9.02035) & & \\
\hline \multicolumn{5}{|l|}{$\begin{array}{l}\text { Tempoh Perkhidmatan } \\
\text { dengan Kementerian }\end{array}$} \\
\hline \multirow[t]{4}{*}{ Kesihatan Malaysia } & Kurang 1 tahun & $11.2727(9.34977)$ & $.978(144)$ & 0.405 \\
\hline & $2-10$ tahun & $12.4000(9.09528)$ & & \\
\hline & 11-20 tahun & $9.5000(8.15475)$ & & \\
\hline & 21 tahun dan lebih & $11.4167(9.54852)$ & & \\
\hline
\end{tabular}

$\mathrm{N}=145, *$ Significant level at 0.05

\section{Perbincangan Kajian}

Secara umumnya kajian ini mendapati sebilangan besar responden mengalami tahap kemurungan yang rendah $(60.7 \%$ ) manakala $18.6 \%$ mengalami sederhana dan $2.8 \%$ tahap teruk. Jururawat yang bertugas dalam bidang kesihatan secara umumnya telah dilatih untuk menguruskan tekanan yang dihadapi dalam kehidupan semasa bertugas. Oleh yang demikian, hasil dapatan kajian menunjukkan tahap kemurungan yang rendah dalam kalangan jururawat adalah berpunca daripada pengetahuan yang tinggi dalam menguruskan tekanan. Hal ini disokong oleh hasil dapatan daripada kajian lepas yang menunjukkan bahawa sebanyak $70 \%$ jururawat yang bertugas di unit rawatan rapi hanya mengalami kemurungan yang minima dan ringan walaupun sentiasa bertugas dalam keadaan yang sibuk dan memerlukan penumpuan maksima terhadap tugas yang dibuat (Vargas \& Dias, 2011). Oleh yang demikian, tahap pengetahuan dan amalan bagi jururawat mengenai kesihatan mental mereka sendiri adalah yang terpenting dan harus bermula lebih awal. Selain itu juga bimbingan oleh generasi jururawat yang telah belajar mengatasi tekanan kerja dan beban selama beberapa dekad berperanan dapat membantu golongan jururawat muda yang berisiko tinggi untuk mengalami kemurungan (Ohler et al., 2010).

Hasil dapatan kajian ini juga menunjukkan terdapat jururawat yang mengalami tahap kemurungan yang sederhana dan teruk. Hal ini dikaitkan dengan risiko tekanan psikologi yang lebih tinggi, termasuk status pekerjaan yang tidak selamat, beban kerja yang berat, tindak balas emosi terhadap pesakit yang menderita dan mati, masalah organisasi dan juga berlaku perselisihan atau konflik di tempat kerja (Tran et al., 2019). Selain itu juga menurut kajian yang dijalankan di Vietnam dalam kalangan jururawat yang bertugas menunjukkan bahawa persekitaran kerja yang tertekan dengan beban kerja yang tinggi, kekurangan kakitangan kesihatan yang mahir, dan infrastruktur yang tidak mencukupi serta peralatan perubatan yang berkurangan dikaitkan dengan perkembangan masalah kesihatan mental dalam kalangan jururawat (Tran et al., 2019). Tourigny et al. (2010) menyatakan bahawa jururawat di Jepun 
memerlukan latihan dalam teknik mengatasi tekanan dan juga sokongan psikologi terutamanya untuk mengurangkan gejala keletihan mereka. Di samping itu juga, menurut kajian yang dijalankan dalam kalangan kakitangan yang berkhidmat di Hospital Kerajaan Sibu, Sarawak mendapati bahawa kekurangan bimbingan dan sokongan daripada pihak atasan serta kualiti yang rendah dalam latihan dan pengembangan pengurusan menjadi penyumbang utama terhadap masalah tekanan di tempat kerja. Mereka juga mengalami diskriminasi yang terlindung dan pilih kasih serta kekurangan maklum balas mengenai prestasi sendiri di tempat kerja. Selain itu, terdapat kekurangan staf dan kadar pusingan ganti kerja yang tidak tetap serta perkongsian tugas dan tanggungjawab adalah secara tidak saksama di samping ciri-ciri struktur dan reka bentuk organisasi yang tidak efisien dan kekurangan rundingan dan komunikasi juga membawa kepada faktor tekanan kerja yang utama dalam perkhidmatan (Ganing et al., 2020).

Di samping itu juga, kajian ini mendapati terdapat perbezaan yang signifikan bagi faktor umur terhadap tahap kemurungan dalam kalangan jururawat. Dapatan kajian yang dijalankan dalam kakitangan kerajaan yang bertugas di Hospital Sibu, Sarawak turut menemui dapatan yang sama di mana faktor umur mempunyai perbezaan yang signifikan dengan kemurungan. Kumpulan umur pertengahan, individu yang sudah berkahwin, berkhidmat lebih dari lima tahun dan bekerja pada waktu syif turut mempunyai skor mean yang tinggi (Ganing et al., 2020). Manakala menurut Lee dan Kim (2015) jururawat lebih muda usia adalah mengalami kemurungan dalam pekerjaan. Sara et al. (2018) turut mendapati terdapat perkaitan antara tekanan psikososial di tempat kerja dan gejala kemurungan antara pekerja bagi golongan pertengahan umur. Hal ini disebabkan dari tahun ke tahun semakin ramai pekerja akan meningkat umur dan memerlukan pendekatan pengurusan yang berbeza dalam kehidupan.

\section{Kesimpulan}

Kajian ini mendapati sebilangan besar responden mengalami kemurungan yang rendah. Hal ini menunjukkan kebanyakan jururawat dapat mengawal masalah dan tekanan yang dihadapi dalam kehidupan sekali gus dapat mengawal emosi masing-masing. Walau bagaimanapun masih terdapat jururawat yang mengalami kemurungan di tahap sederhana dan teruk yang tidak boleh diabaikan. Kajian ini merupakan kajian yang berorientasikan bidang psikologi yang sering dipandang remeh oleh ramai pihak namun pada hakikatnya perkara ini boleh mendatangkan kesan negatif dalam kehidupan. Justeru itu kesan dan akibat daripada tekanan psikologi ini seharusnya diberi perhatian dan perlu ditangani dengan betul bagi mengelakkan jururawat sebagai anggota yang bertanggungjawab memberikan perkhidmatan kesihatan berdepan dengan masalah mental yang boleh mengganggu kehidupan pada masa akan datang.

\section{Penghargaan}

Jutaan terima kasih kepada Ketua Pengarah dan Timbalan Ketua Pengarah Kesihatan (Penyelidikan dan Sokongan Teknikal), Kementerian Kesihatan Malaysia atas kelulusan menerbitkan kertas kajian ini. Ucapan terima kasih juga dizahirkan kepada pihak Pejabat Kesihatan Daerah atas kebenaran pengumpulan data dan juga kepada jururawat yang mengambil bahagian dalam penyelidikan ini serta semua pihak yang menyokong dan menyumbang secara langsung atau tidak langsung.

Kod projek kajian adalah NMRR-15-1239-27009 telah mendapat kelulusan etika daripada Kementerian Kesihatan Malaysia (5) KKM/NIHSEC/P15-1150 (22 September 2015).

\section{Rujukan}

Abdullah, N. A. S., Rosli, N. A., Valaitham, S. A., \& Rosli, N. A. (2018). Kemurungan Dalam Kalangan Mualaf Di Pusat Pengajian PERKIM Wilayah Persekutuan. Malaysian Online Journal of Counseling, 5(1), 52-63.

Ahmad, Zainal. (2018). Kemurungan: Apa Yang Anda Perlu Tahu. Psikologis, february, 1-8. 
file:///C:/Users/Acer/Downloads/Kemurungan_-_Apa_Yang_Anda_Perlu_Tahu (2).pd

Aisha, N. F., \& Ruslan, R. (2020). Faktor -Faktor Tekanan Kerja Yang Mempengaruhi Keseimbangan Kehidupan Kerja Dalam Kalangan Jururawat. Research in Management of Technology and Business, 1(1), 381-390. https://doi.org/10.30880/rmtb.2020.01.01.031

Ayub, N. (2008). Burnout dan komitmen terhadap organisasi di kalangan jururawat hospital. Jurnal Kemanusiaan, 12(1979), 73-86.

Bahari, L. ak T. F. H., \& Nawi, N. H. M. (2016). Campuran kebimbangan dan kemurungan dalam kalangan ibu bapa kanak-kanak kurang upaya fizikal di luar bandar Sabah. Jurnal Psikologi Malaysia, 30(2), 61-73.

Beck, A.T., \& Alford, B. A. (1967). Depression Causes and Treatment (2nd Ed.). University of Pennsylvania Press.

Beck, A. T., Ward, C. H., Mendelson, M., Mock, J., \& Erbaugh, J. (1961). An Inventory for Measuring Depression. In Archives of General Psychiatry (Vol. 4, Issue 6). https://doi.org/10.1001/archpsyc.1961.0171012003100

Fariza Md.Sham. (2019). Murung Tanda Jiwa Tidak Tenang. In Berita Harian (p. 65).

Ganing, C. F., Hassan, M. M., \& Wan Hamzah, W. N. N. (2020). Faktor-faktor yang Mempengaruhi Tekanan Kerja di kalangan Kakitangan Hospital Kerajaan. Malaysian Journal of Social Sciences and Humanities (MJSSH), 5(10), 151-177. https://doi.org/10.47405/mjssh.v5i10.522

Halina, M. N. (2019). Guru, jururawat tertekan banyak kerja. In Berita Harian. https://www.bharian.com.my/wanita/lain-lain/2019/01/522186/guru-jururawat-tertekan-banyakkerja.

Hanidah Sumadi. (2013). Hubungan personaliti dengan kemurungan pelajar di sebuah sekolah menengah agama Johor. Universiti Teknologi Malaysia.

Kementerian Kesihatan Malaysia. (2011). Laporan Tahunan Kementerian Kesihatan Malaysia 2011.

Lee, K. J., \& Kim, J. I. (2015). Relating factors for depression in Korean working women: Secondary analysis of the fifth Korean National Health and Nutrition Examination Survey (KNHANES V). Asian Nursing Research, 9(3), 265-270. https://doi.org/10.1016/j.anr.2015.07.002

Marcus, M., Yasamy, M. T., van Ommeren, M., \& Chisholm, D. (2012). Depression, a global public health concern. WHO Department of Mental Health and Substance Abuse, 1-8. http://www.who.int/mental_health/management/depression/who_paper_depression_wfmh_2012.pd

Mohamed, M. N. (2001). Pengantar Psikologi: Satu Pengenalan Asas kepada Jiwa dan Tingkah Laku Manusia.

Mohd Suhaimi Mohamad \& Mohd Haazik Mohamed. (2020). Jenis Personaliti dan Tahap Kesihatan Mental dalam Kalangan Mahasiswa di Institusi Pengajian Tinggi. Jurnal Personalia Pelajar, 23(1), 7-17.

Nasir, R., Zamani, Z. A., Khairudin, R., Sulaiman, W. S. W., Sani, M. N. M., \& Amin, A. S. (2016). Hubungan antara kesunyian dan sokongan sosial terhadap kemurungan dalam kalangan wanita hamil tanpa nikah. Jurnal Psikologi Malaysia, 30(1), 152-159.

Norhayati Ibrahim, Asmawati Desa, \& Norella Kong. (2010). Kualiti Hidup Kesihatan Dan Persepsi Terhadap Penyakit Pesakit Buah Pinggang Tahap Akhir Di Malaysia. Jurnal Psikologi Malaysia, 24, 63-78. http://spaj.ukm.my/ppppm/jpm/article/viewFile/84/63

Ohler, M. C., Kerr, M. S., \& Forbes, D. A. (2010). Depression in nurses. Canadian Journal of Nursing Research, 42(3), 66-82. https://doi.org/10.7939/R39882N4Q

Robert V. Krejcie, D. W. M. (1970). Determining Sample Size For Research Activities. Educational And Psychological Measurement, 30, 607-610. https://journals.sagepub.com/doi/pdf/10.1177/001316447003000308

Sara, J. D., Prasad, M., Eleid, M. F., Zhang, M., Jay Widmer, R., \& Lerman, A. (2018). Association between work-related stress and coronary heart disease: A review of prospective studies through the job strain, effort-reward balance, and organizational justice models. Journal of the American Heart Association, 7(9), 1-15. https://doi.org/10.1161/JAHA.117.008073

Sehrish, H., \& Waqar, H. (2020). The different levels of depression and anxiety among Pakistani professionals. Insights on the Depression and Anxiety, 4(1), 012-018. https://doi.org/10.29328/journal.ida.1001014

Tourigny, L., Baba, V. V., \& Wang, X. (2010). Burnout and depression among nurses in Japan and China: The moderating effects of job satisfaction and absence. International Journal of Human Resource Management, 21(15), 2741-2761. https://doi.org/10.1080/09585192.2010.528656 
DOI: https://doi.org/10.47405/mjssh.v6i12.1209

Tran, T. T. T., Nguyen, N. B., Luong, M. A., Bui, T. H. A., Phan, T. D., Tran, V. O., Ngo, T. H., Minas, H., \& Nguyen, T. Q. (2019). Stress, anxiety and depression in clinical nurses in Vietnam: A crosssectional survey and cluster analysis. International Journal of Mental Health Systems, 13(1), 1-11. https://doi.org/10.1186/s13033-018-0257-4

Vargas, D. de, \& Dias, A. P. V. (2011). Depression prevalence in Intensive Care Unit nursing workers: a study at hospitals in a northwestern city of São Paulo State. Revista Latino-Americana de Enfermagem, 19(5), 1114-1121. https://doi.org/10.1590/s0104-11692011000500008

World Health Organization. (2017). Depression and Other Common Mental Disorders Global Health Estimates.

Yahya, N. A., \& Md. Sham, F. (2020). Sejarah dan Simptom Kemurungan: Kajian Literatur. Sains Insani, 5(1), 34-42. https://doi.org/10.33102/sainsinsani.vol5no1.130

Yeap, R., \& Low, W. Y. (2009). Mental health knowledge, attitude and help-seeking tendency: A Malaysian context. Singapore Medical Journal, 50(12), 1169-1176. 